\title{
EKSISTENSI WANITA PADA PENAYANGAN IKLAN DI TELEVISI DALAM IMPLEMENTASI TEORI GENDER
}

\author{
Surya Darma \\ Program Studi Televisi dan Film, Universitas Potensi Utama \\ E-mail: surya.darma_pu@yahoo.com
}

\begin{abstract}
ABSTRAK
Iklan kecap ABC - Jadikan masakan ibu pilihan pertama menampilkan Darius Sianthriya dan Donna Agnesia sebagai brand ambasador pada official channel HeinzABC Indonesia merupakan channel resep dan tips memasak yang membantu ibu-ibu dalam membuat sajian yang lezat untuk keluarga. Website resmi pada channel ini yaitu www.heinzabc.co.id merupakan website dengan penyajian informasi menarik seputar informasi memasak dengan menggunakan merek ABC. Iklan dipandang berhasil apabila mampu menarik minat audience untuk terlibat dalam memahami pesan yang disampaikan dalam iklan tersebut. Simbol yang terlihat yaitu rasa lapar atau selera makan yang ditunjukkan Suami terhadap Istri dengan memberi Simbol yang ditampakkan pada bahasa dan gerak tubuh Darius dengan ekspresi menghirup udara sambil memejamkan mata. Gender adalah suatu konsep yang digunakan untuk mengidentifikasi perbedaan antara laki-laki dan perempuan yang dipandang dari segi sosial budaya. Wanita dalam penayangan iklan kecap ABC - Jadikan masakan ibu pilihan pertama memberi simbol bahwa seorang Istri harus dapat membahagiakan keluarganya dengan cara pandai memasak dan memilih produk yang tepat agar makanan yang dimasak semakin nikmat jika dihidangkan dengan keluarga.
\end{abstract}

Kata Kunci : Iklan Kecap ABC, Teori Gender, Eksistensi Wanita, Konotasi, Denotasi, Mitos.

\begin{abstract}
$A B C$ soy sauce ads - make it the first choice of the mother cuisine featuring Darius Sianthriya and Donna Agnesia as brand Ambassador in Indonesia is the official channel HeinzABC channel recipes and cooking tips that help mothers in making delicious dishes for the family. Official website of the channel at www.heinzabc.co.id is the website with presentation of interesting information about the cooking information by using the ABC brand. The ads were viewed successfully in capable of attracting audience to engage in understanding the messages conveyed in these ads. The symbol is visible i.e. hunger or appetite, indicated her husband against Wife by giving the Symbol showed on the language and gestures of Darius with his expression closed his eyes while breathing. Gender is a concept that is used to identify the differences between men and women, viewed in terms of its social culture. The woman in the ad-serving ABC soy sauce-Make
\end{abstract}

Keywords: ABC Ketchup Ads, Gender Theory, Women's Existence, Connotation, Denotation, Myth.

\section{PENDAHULUAN}

Iklan adalah media komunikasi antar komunikator dalam suatu sarana penyampaian produk atau jasa ke publik. Tujuan iklan yaitu memberikan informasi dan membujuk para 
konsumen untuk mencoba atau mengikuti apa yang ada di iklan tersebut, dapat berupa aktifitas mengkonsumsi produk dan jasa yang ditawarkan (Antonius, 2016: 16).

Iklan dipandang berhasil apabila mampu menarik minat audience untuk terlibat dalam memahami pesan yang disampaikan dalam iklan tersebut. Kegiatan periklanan membutuhkan adanya suatu media, yaitu media periklanan yang meliputi segenap perangkat yang dapat memuat atau membawa pesan-pesan penjualan pada calon pembeli. Dari berbagai media yang digunakan sebagai sarana untuk beriklan, televisi merupakan salah satu media yang cepat dalam penyampaian pesan bagi produsen untuk mengiklankan produknya (Rahmawati et al, 2010: 221).

Official Channel HeinzABC Indonesia merupakan channel resep dan tips memasak yang membantu ibu-ibu dalam membuat sajian yang lezat untuk keluarga. Channel HeinzABC ini memiliki 142,833 subscribers. Website resmi pada channel ini yaitu www.heinzabc.co.id merupakan website dengan penyajian informasi menarik seputar informasi memasak dengan menggunakan merek ABC. (Sumber : https://www.youtube.com/watch?v=J9U1EdZRDYQ : diakses 10 Desember 2018 Pukul 09-10 WIB).

Iklan kecap ABC - Jadikan masakan ibu pilihan pertama menampilkan Darius Sianthriya dan Donna Agnesia sebagai brand ambasador. Pada iklan tersebut terlihat figure seorang Ibu berperan penting dalam keluarga, Ibu yang mempersiapkan makanan untuk anak-anaknya, yang merupakan sosok figure sebagai "penyelamat perut" dengan kata lain seorang Ibu dapat bekerja part time untuk kebahagiaan keluarga dengan tetap memegang predikat Ibu rumah tangga. Sedangkan figure seorang Ayah adalah seorang yang mencari nafkah untuk keluarga sehingga terlihat pada frame tersebut seorang Ayah dan anak-anaknya sedang menunggu masakan dari Ibu, pada frame tersebut memberi tanda bahwa tugas seorang Ayah mencari nafkah selanjutnya tugas Ibu mengatur segala keperluan keluarga serta memasak sebagai petanda wujud bakti seorang istri terhadap suami.

Referensi penulisan pustaka yang dirujuk dalam tulisan ini adalah sebagai betikut : Artikel Gora, 2016: 178 berjudul "Representasi Perempuan dalam Iklan Televisi (Studi Analisis Semiotika Iklan Beng Beng Versi "Great Date")" memberi kesimpulan bahwa media memiliki kekuatan untuk membangun perspektif melalui pesan yang ditampilkan melalui visualisasi iklan. Hubungan tanda-penanda disini iklan apabila dilihat dari hubungan penyampaian pesan masih bersifat ambigu sehingga hubungan antara promosi produk dan pesan iklan terkadang tidak sesuai dengan tujuan iklan tersebut dibuat. Pada artikel tersebut memberikan kesimpulan akhir bahwa tidak ada signifikansi hubungan antara produk dengan peran wanita. Visualisasi iklan hanya untuk menunjukkan cerita kebahagiaan pasangan dan dari sisi varian wajah (mimic) perempuan pada iklan sebagai karakter utama dan penguatan kreatif iklan bukan untuk penguatan dari sisi spesifikasi produknya (Gora, 2016: 151).

Keterkaitan penelitian penulis dengan penelitian tersebut yaitu sama-sama menggunakan semiotika Roland Barthes. Penelitian tersebut menggunakan iklan beng beng versi "great date" sebagai fokus objek utama yang merepesentasikan cerita kebahagiaan pasangan dari sisi varian wajah (mimic), sedangkan penelitian penulis menggunakan iklan kecap ABC - Jadikan masakan ibu pilihan pertama untuk mengungkap eksistensi atau peran penting seorang wanita dalam status keluarga.

Artikel Rahmawati et al, 2010: 221 menjelaskan bahwa ketidak seimbangan gender terhadap perempuan dalam rumah tangga. Hal ini terjadi karena dominasi laki-laki terhadap perempuan yang dikuatkan dengan nilai-nilai paternalistik. Perempuan berada dalam posisi yang dirugikan, sehingga terjadi ketidakseimbangan dalam pembagian pekerjaan rumah tangga. Laki-laki atau kepala rumah tangga selalu berada di atas 
perempuan atau ibu rumah tangga. Penelitian ini mendeskripsikan bias gender dalam iklan televisi Attack Easy versi "Ibuku Cantik saat Mencuci" dengan analisis semiologi Roland Barthes. Hasilnya terdapat kesetaraan gender dan ketidakseimbangan gender. Perempuan mampu mengerjakan pekerjaan berat yang biasa dikerjakan laki-laki, namun masih ditempatkan sebagai ibu rumah tangga (Rahmawati, et al, 2010: 221).

Persamaan peneliti penulis dengan penelitian tersebut yaitu sama-sama membahas keterkaitan wanita dalam status sosial dimasyarakat. Pada penelitian tersebut merepresentasikan perempuan sebagai posisi yang dirugikan sehingga terjadi ketidakseimbangan dalam pembagian rumah tangga, pada penelitian penulis mengungkap eksistensi atau peran penting seorang wanita dalam status keluarga. Pada objek kajian penelitian tersebut menggunakan iklan beng beng versi "great dete", sedangkan penelitian penulis menggunakan objek kajian iklan kecap ABC - Jadikan masakan ibu pilihan pertama. Sehingga penelitian penulis dengan penelitian tersebut berbeda.

Artikel Mujahidin, 2010: 1 dengan judul "Dinamika Gender dan Peran Perempuan dalam Ekonomi Keluarga" menjelaskan bahwa artikel tersebut mendeskripsikan tentang dinamika dan diskursus wacana gender yang telah berhasil menebus budaya paternalistik. Perjuangan dan gerakan gender telah meretas persepsi masyarakat yang menganggap perempuan sebagai makhluk lemah yang dinomorduakan dalam realitas sosial masyarakat. Dalam wilayah pragmatis, paham gender berimplikasi terhadap hubungan antara laki-laki dengan perempuan dalam status hubungan suami istri. Kesadaran gender telah membuka ruang kesetaraan antara suami dan istri dalam posisi sama dalam persoalan hak dan kewajiban dalam menjalankan kehidupan rumah tangga. Termasuk di dalamnya tanggungjawab perlindungan, keamanan, kesejahteraan, dan nafkah untuk keluarga (Mujahidin, 2010: 1).

Persamaan peneliti penulis dengan penelitian tersebut yaitu sama-sama mengungkap eksistensi wanita menggunakan teori gender. Perbedaan penelitian tersebut yaitu pada objek kajian mendeskripsikan tentang dinamika dan diskursus wacana gender yang telah berhasil menebus budaya paternalistik, sedangkan pada penelitian penulis yaitu peran penting wanita dalam status keluarga dengan predikat ibu rumah tangga. Demikian yang telah dijelaskan tersebut penulis mengungkap eksistensi wanita pada penayangan iklan di televisi dalam implementasi teori gender dengan teori pembedah semiotika Roland Barthes sebagai pemecahan masalah yang terdiri dari konotasi, denotasi, dan mitos.

\section{STUDI LITERATUR}

\subsection{Pengertian Iklan}

Iklan merupakan metode dalam penyampaikan ide dan gagasan yang memberikan makna simbolik melalui penayangan visual dalam sebuah iklan. Sesuai dengan karakternya, iklan merupakan bentuk nyata yang tersebar di masyarakat luas sebagai pemahaman terhadap nilai-nilai tertentu (Vera, 2014: 43). Keunikan yang terdapat pada pesan iklan sebagai bentuk kreativitas berupa representasi fenomena yang memberi makna dan kesan kepada penonton atau pembaca iklan (Vera dalam Tenggono dan Sulistyarini, 2016: 394).

Tilman dan Kirkpatrick menjelaskan bahwa iklan merupakan bentuk komunikasi massa yang menawarkan janji kepada konsumen. Pesan yang terdapat pada iklan mampu mempengaruhi konsumen untuk memenuhi kebutuhan dalam memperoleh barang dan jasa serta kualitas barang dan jasa. Menurut Wright iklan merupakan media komunikasi massa. Pembedaan iklan dengan teknik komunikasi pemasaran yang lain adalah komunikasi yang non-personal, jadi iklan memakai media dengan menyewa ruang dan waktu. Disamping itu peranan iklan antara lain dirancang untuk memberikan saran pada orang supaya mereka 
membeli suatu produk tertentu membentuk hasrat memiliknya dengan mengkonsumsinya secara tepat (Sopianah, 2010: 17).

\subsection{Perempuan, Gender, dan Media Iklan}

Gender adalah suatu konsep yang digunakan untuk mengidentifikasi perbedaan antara laki-laki dan perempuan yang dipandang dari segi sosial budaya. Gender dibentuk oleh masyarakat dan bukan bersifat kodrati. Berbeda dengan seks yang tidak dapat dipertukarkan karena merupakan kodrat Tuhan, sedangkan gender dapat berubah manakala masyakarat menghendakinya. Secara struktur biologis, manusia terdiri dari laki-laki dan perempuan, dimana masing-masing memiliki alat dan fungsi biologis yang melekat serta tidak dapat dipertukarkan. Laki-laki memiliki penis, jakun, memproduksi sperma dan sebagainya. Perempuan memiliki organ ovarium, memproduksi sel telur, menyusui, dan melahirkan (Rahmawati, et al, 2010: 223).

Sedangkan konsep gender, adalah suatu sifat yang melekat pada kaum laki-laki maupun perempuan yang merupakan: pertama, hasil konstruksi sosial maupun kultural, misalnya perempuan dikenal lemah lembut, cantik, emotional, keibuan. Sementara lakilaki dianggap kuat, rasional, jantan, dan perkasa. Terdapat beberapa karakter dari sifat-sifat tersebut yang dapat dipertukarkan, misalnya: ada laki-laki yang lemah lembut dan emosional, sementara ada juga perempuan yang kuat dan rasional. Kedua, perubahan yang terjadi dari waktu ke waktu dan dari tempat ke tempat lain, misalnya pada jaman dulu di suatu suku terdapat perempuan lebih kuat dari laki-laki, tapi pada jaman dan tempat yang lain yang berlaku sebaliknya. Ketiga, adalah dari kelas ke kelas masyarakat yang lain yang juga berbeda. Pada perempuan kelas bawah di pedesaan pada suku tertentu lebih kuat dari laki-laki. Semua yang dapat dipertukarkan antara sifat perempuan dan laki-laki berubah dari waktu ke waktu, serta berbeda dari suatu tempat ke tempat yang lain, serta dari kelas ke kelas yang lain. Itulah yang disebut konsep gender (Fakih dalam Rahmarwati, 2010: 223).

Perempuan memang telah menjadi fenomena komoditas yang tidak terelakkan dalam kancah komunikasi iklan. Perempuan telah menjadi sarana legimitasi daya tarik terhadap aktualisasi nilai produk. Sebuah produk yang pada kenyataannya mempunyai fungsi yang general, telah dikomunikasikan tidak lagi bersifat fungsional tetapi sudah bergeser ke arah konsep gender. Femininitas atau maskulinitas seringkali menjadi ajang manifestasi untuk membuat komoditi atau produk mempunyai nilai tertentu. 'Jantan', 'maskulin', 'eksklusif', Pemberani telah menjadi idiom yang dimiliki oleh komoditi seperti rokok, suplemen, parfum, jamu atau obat kuat lelaki, otomotif, dan lain sebagainya. Sedangkan sabun, shampoo, peralatan rumah tangga dan elektronik sering dimanifestasikan sebagai komoditi yang dekat dengan wilayah femininitas (Rahmawati, et al, 2010: 223-224).

\subsection{Teori Semiotika Roland Barthes}

Istilah semiotika lazim dipakai oleh ilmuwan Amerika, sedangkan ilmuwan Eropa lebih banyak menggunakan istilah semiologi. Semiotika adalah cabang ilmu yang mengkaji persoalan tanda dan segala sesuatu yang berhubungan dengan tanda, seperti sistem tanda dan proses yang berlaku bagi tanda, Semiotik adalah tanda sebagai tindak komunikasi yang disempurnakan menjadi model sastra yang mempertanggungjawabkan semua faktor dan aspek substansi untuk pemahaman gejala kesusastraan sebagai alat komunikasi yang khas dalam masyarakat (Rusmana, 2014: 5). 
Semiotik telah menjadi wilayah lintas disiplin yang menarik untuk dicermati. Berbagai disiplin serta-merta memiliki titik sentuh ketika mengkaji 'realitas' yang dimediasi. Dari waktu ke waktu semiotik digunakan sebagai pendekatan untuk memecahkan masalah praktis di samping mengalami perkembangan secara teoretis (Christomy dan Yuwono, 2004: 1).

Pada mulanya, istilah semiotik (semieon) digunakan oleh orang Yunani untuk merujuk pada sains, yang mengkaji sistem perlambangan atau sistem tanda dalam kehidupan manusia. Dari akar kata inilah terbentuk istilah semiotik, yaitu kajian sastra yang bersifat saintifik yang meneliti sistem perlambangan dan berhubungan dengan tanggapan dalam karya (Rusmana, 2014: 5).

Roland Barthes dikenal sebagai salah seorang pemikir strukturalis yang mempraktikkan model linguistik dan semiologi Saussurean. Ia juga intelektual dan kritikus sastra Prancis yang ternama; eksponen penerapan srukturalisme dan semiotika pada studi sastra. Bertens (2001: 208) menyebutnya sebagai tokoh yang memainkan peranan sentral dalam strukturalisme tahun 1960-an dan 70-an.

Salah satu area penting yang dirambah Barthes dalam studinya tentang tanda adalah peran pembaca (the reader). Konotasi, walaupun merupakan sifat asli tanda, membutuhkan keaktifan pembaca agar dapat berfungsi. Barthes secara panjang lebar mengulas apa yang sering disebut sebagai sistem pemaknaan tataran ke-dua, yang dibangun di atas sistem lain yang telah ada sebelumnya. Sistem kedua ini disebut dengan konotatif, yang didalam Mythologies-nya secara tegas ia bedakan dari denotatif atau sistem pemaknaan tataran pertama. Barthes menciptakan peta tentang bagaimana tanda bekerja (Sobur, 2006:69).

Tabel 1. Tabel Peta Tanda Roland Barthes

\begin{tabular}{|c|c|c|}
\hline $\begin{array}{c}\text { 1. } \begin{array}{c}\text { Denotative sign } \\
\text { (tanda denotatif) }\end{array} \\
\text { 3. } \begin{array}{c}\text { CONNOTATIVE SIGNIFIER } \\
\text { (PENANDA KONOTATIF) }\end{array}\end{array}$ & $\begin{array}{l}\text { Signified } \\
\text { (petanda) }\end{array}$ & $\begin{array}{c}\text { CONNOTATIVE SIGNIFIED } \\
\text { (PETANDA KONOTATIF) }\end{array}$ \\
\hline \multicolumn{2}{|c|}{ 5. CONNOTATIVE SIGN (TANDA KONOTATIF) } \\
\hline
\end{tabular}

(Sumber: Sobur, 2006: 69)

Dari peta tanda Roland Barthes diatas, terlihat bahwa denotatif (3) terdiri atas penanda (1) dan petanda (2). Akan tetapi, pada saat bersamaan tanda denotai adalah juga penanda konotatif (4). Dengan kata lain, hal tersebut merupakan unsur material: hanya jikan anda mengenal tanda "singa", barulah konotasi seperti harga diri, kegarangan, dan keberanian menjadi mungkin (Sobur, 2006: 69).

Pengaplikasian teori semiotika Roland Barthes untuk mengungkap Eksistensi Wanita Pada Penayangan Iklan Di Televisi Dalam Implementasi Teori Gender.

\section{PEMBAHASAN}

\subsection{Metode Penelitian}

\section{a. Jenis Penelitian}

Metode yang digunakan pada penelitian ini menggunakan metode penelitian kualitatif dengan mendefenisikan konsep-konsep yang umum dengan pendekatan analisis semiotika. Semiotika adalah cabang ilmu yang mengkaji persoalan tanda dan segala sesuatu yang berhubungan dengan tanda, seperti sistem tanda dan proses yang berlaku bagi tanda, Semiotik adalah tanda sebagai tindak komunikasi yang disempurnakan menjadi model sastra yang mempertanggung jawabkan semua faktor dan aspek substansi untuk pemahaman gejala kesusastraan sebagai alat komunikasi yang khas dalam masyarakat (Rusmana, 2014: 5). 


\section{b. Objek Penelitian dan Unit Analisis}

Objek Penelitian dan Unit Analisis pada penelitian ini adalah "Eksistensi Wanita pada Penayangan Iklan Di Televisi dalam Implementasi Teori Gender". Sedangkan unit penelitian yaitu mengungkap Eksistensi Wanita pada Penayangan Iklan Di Televisi Dalam Implementasi Teori Gender dengan teori pembedah semiotika Roland Barthes.

\section{c. Jenis Sumber Data}

Sumber data yang digunakan penulis yaitu : data primer adalah data yang diperoleh dari Iklan "kecap ABC - Jadikan masakan ibu pilihan pertama" kemudian mengungkap eksistensi wanita pada penayangan iklan di televisi dalam implementasi teori gender dan memilih beberapa potongan visual atau gambar yang diperlukan. Selanjutnya data sekunder didapat dari beberapa literatur-literatur yang mendukung data primer seperti internet, dan buku-buku terkait.

\section{d. Teknik Pengumpulan Data}

Teknik pengumpulan data yang digunakan yaitu : Studi kepustakaan yang merupakan sebuah proses mencari berbagai literatur, hasil kajian atau studi yang berhubungan dengan penelitian yang akan dilakukan. Ada berbagai jenis sumber pustaka (literature) yang dapat dimanfaatkan. Pada dasarnya, semua sumber tertulis dapat dimanfaatkan sebagai sumber pustaka, baik buku teks, surat kabar, majalah, brosur, tabloid, dan sebagainya. Literatur juga dapat diperoleh melalui media internet (Martono, 2010: 42).

Observasi atau pengamatan dapat didefenisikan sebagai "perhatian yang terfokus terhadap kejadian, gejala, atau sesuatu". Adapun observasi ilmiah adalah "perhatian terfokus terhadap gejala, kejadian atau sesuatu dengan maksud menafsirkannya, mengungkapkan faktor-faktor penyebabnya, dan menemukan kaidah-kaidah yang mengaturnya (Garayibah, et al dalam Emzir, 2011: 38). Observasi dilakukan dengan melakukan pengamatan langsung seperti menonton dan mengamati iklan "kecap ABC Jadikan masakan ibu pilihan pertama" sebagai acuan penting terkait peran seorang wanita sebagai ibu rumah tangga dalam keluarga. Tahap selanjutnya mengamati, meneliti, dan menganalisis dengan penelitian yang digunakan.

Data primer dan sekunder terkumpul kemudian diklarifikasikan sesuai dengan pertanyaan penelitian yang telah ditentukan. Setelah data terklarifikasi, dilakukan analisis data dengan menggunakan teknik semiotika Roland Barthes.

\subsection{Analisis Kajian}

Objek kajian pada penelitian ini yaitu pengungkapan eksistensi wanita pada penayangan iklan kecap ABC - Jadikan masakan ibu pilihan pertama dengan teori gender analisis semiotika Roland Barthes yang menjadi titik acuan penulis.

Tabel 2. Adegan Darius Mencium Aroma Masakan Istrinya

\begin{tabular}{|l|l|}
\hline Signified (Penanda) & \multicolumn{1}{|c|}{ Signifier (Petanda) } \\
\hline & $\begin{array}{l}\text { Pada scene 1 terlihat saat Darius sedang } \\
\text { menunggu tayangan bola pada salah satu siaran } \\
\text { televisi dan tercium aroma masakan istri yang } \\
\text { mengalihkan perhatiannya. }\end{array}$ \\
\hline
\end{tabular}




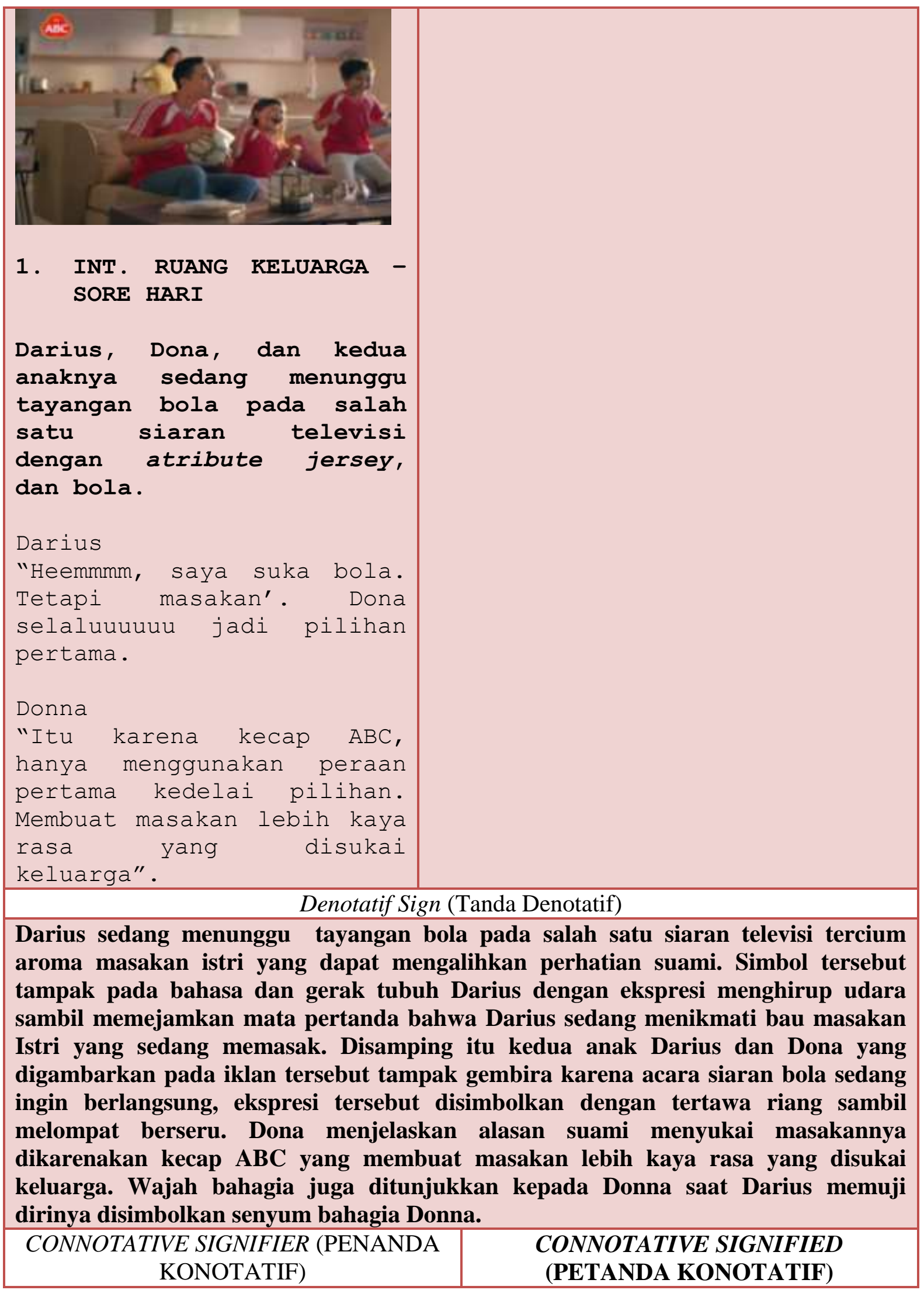




\begin{tabular}{|l|l|}
\hline $\begin{array}{l}\text { Sikap yang ditunjukkan seseorang } \\
\text { terhadap sesuatu aroma yang disukai } \\
\text { ditandai dengan menghirup udara sambil } \\
\text { memejamkan mata pertanda bahwa }\end{array}$ & $\begin{array}{l}\text { Darius memuji Donna bahwa masakan } \\
\text { Istrinya sangat enak sehingga bola yang ia } \\
\text { gemaripun rela ia tinggalkan demi masakan }\end{array}$ \\
$\begin{array}{l}\text { Darius sedang menikmati aroma } \\
\text { masakan Istri yang nikmat. }\end{array}$ & $\begin{array}{l}\text { Istrinya Begitulah yang seharusnya } \\
\text { dilakukan dalam suatu hubungan keluarga } \\
\text { selalu memuji antar keluarga dengan } \\
\text { keluarga yang lain terlebih lagi yang dipuji } \\
\text { adalah seorang istrinya terhadap suaminya } \\
\text { ataupun sebaliknya. }\end{array}$ \\
\hline CONNOTATIVE SIGN (TANDA KONOTATIF) \\
\hline Sifat kasih sayang seorang Ibu untuk memperhatikan dan melayani keluarganya. \\
\hline
\end{tabular}

Simbol adalah objek, kejadian, bunyi bicara, atau bentuk-bentuk tertulis yang diberi makna oleh manusia. Bentuk primer dari simbolisasi oleh manusia adalah melalui bahasa, lukisan, tarian, musik, arsitektur, mimik wajah, gerak gerik, postur tubuh, perhiasan, pakaian, ritus, agama, kekerabatan, nasionalitas, tata ruang, pemilikan barang, dan banyak lagi lainnya. Manusia dapat memberikan makna kepada setiap kejadian, tindakan, atau objek yang berkaitan dengan pikiran, gagasan, dan emosi (Saifuddin, 2005: 289-290).

Simbol yang terlihat pada iklan kecap ABC - Jadikan masakan ibu pilihan pertama yaitu rasa lapar atau selera makan yang ditunjukkan Suami terhadap Istri dengan memberi Simbol yang ditampakkan pada bahasa dan gerak tubuh Darius dengan ekspresi menghirup udara sambil memejamkan mata pertanda bahwa Darius sedang menikmati bau masakan Istri yang sedang memasak. Terlihat pada gambar berikut.

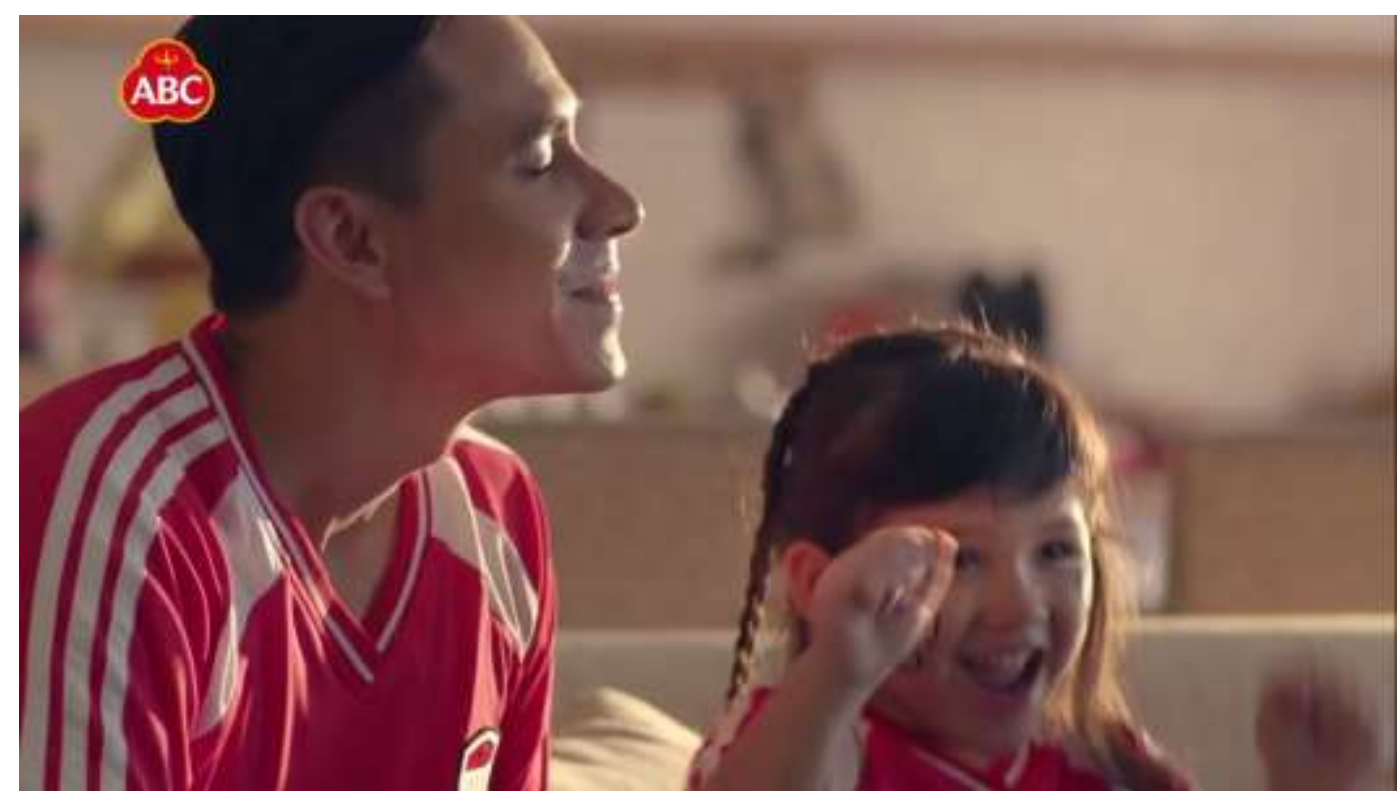

Gambar 1. Ekspresi Darius Menikmati Aroma Masakan Istri

Disamping itu kedua anak Darius dan Dona yang digambarkan pada iklan tersebut tampak gembira karena acara siaran bola sedang ingin berlangsung, ekspresi tersebut disimbolkan dengan tertawa riang sambil melompat berseru. Terlihat pada gambar berikut. 


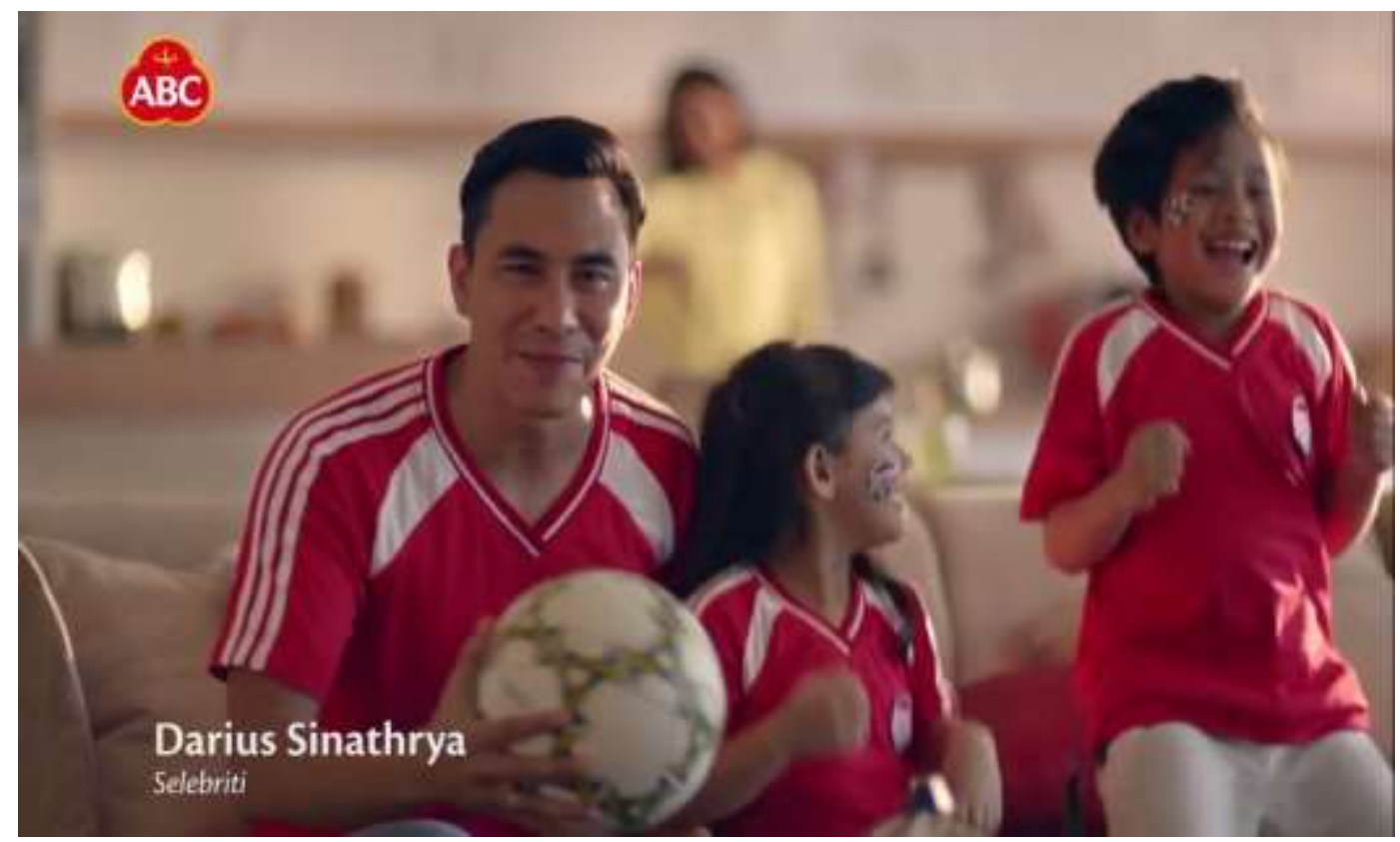

Gambar 2. Ekspresi Anak Terlihat Gembira Saat Acara Bola Ingin Berlangsung

Tabel 3. Adegan Istri Selesai Memasak

\begin{tabular}{|c|c|}
\hline Signified (Penanda) & Signifier (Petanda) \\
\hline $\begin{array}{l}\text { INT. RUANG KELUARGA - } \\
\text { soRE HARI } \\
\text { Istri setelah selesai } \\
\text { memasak menginformaskan } \\
\text { kepada suami dan kedua } \\
\text { anaknya bahwa makanan telah } \\
\text { selesai. } \\
\text { Donna } \\
\text { "Makanan sudah siap, hehe". } \\
\text { Darius "Wahhh, hemmm". } \\
\text { Kedua anaknya mulai } \\
\text { "Pa, bolanya uda m". } \\
\text { tuh". }\end{array}$ & $\begin{array}{l}\text { Pada scene } 3 \text { terlihat saat Istri telah } \\
\text { selesai memasak Istri memberi tahu } \\
\text { keluarganya bahwa makanan telah } \\
\text { selesai. Mendengar hal tersebut Suami } \\
\text { langsung menuju ke dapur dengan } \\
\text { melangkahi sofa. }\end{array}$ \\
\hline
\end{tabular}




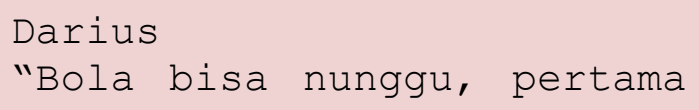

Denotatif Sign (Tanda Denotatif)

Setelah selesai memasak Istri memberi tahu Suami dan kedua anaknya bahwasannya makanan telah selesai, reaksi suamipun tampak bahagia dan ingin segera memakan masakan Istri terlihat dari langkahan kaki pada sofa yang terlihat pada frame yang memberi simbol bahwa Suami ingin segera memakan masakan Istrnya, berbeda dengan kedua anaknya, tampak kedua anak tersebut lebih mementingkan tayangan sepak bola yang akan segera berlangsung ditandai dengan bersikap acuh dan lebih mementingkan acara sepak bola.

\begin{tabular}{c|c}
$\begin{array}{c}\text { CONNOTATIVE SIGNIFIER } \\
\text { (PENANDA KONOTATIF) }\end{array}$ & $\begin{array}{c}\text { CONNOTATIVE SIGNIFIED } \\
\text { (PETANDA KONOTATIF) }\end{array}$
\end{tabular}

Sikap antusias seseorang pada saat lapar terlihat dari cara bersikapnya seperti mencari jalan terdekat dengan melangkahkan kaki ke sofa yang bertujuan ingin segera sampai ke dapur. Sikap ini juga ditunjukkan pada saat terburu-buru.

\section{CONNOTATIVE SIGN (TANDA KONOTATIF)}

Rasa antusias yang ditunjukkan Suami dengan cara terburu-buru ingin mendatangi istrinya kedapur untuk segera memakan masakan Istrinya, hal tersebut membuat Istri merasa di hargai.

Sifat kasih sayang yang ditunjukkan Istri terhadap keluarganya dan rasa antusias Suami terhadap masakan Istri.

Gender adalah suatu konsep yang digunakan untuk mengidentifikasi perbedaan antara laki-laki dan perempuan yang dipandang dari segi sosial budaya. Gender dibentuk oleh masyarakat dan bukan bersifat kodrati. Berbeda dengan seks yang tidak dapat dipertukarkan karena merupakan kodrat Tuhan, sedangkan gender dapat berubah manakala masyakarat menghendakinya. Secara struktur biologis, manusia terdiri dari laki-laki dan perempuan, dimana masing-masing memiliki alat dan fungsi biologis yang melekat serta tidak dapat dipertukarkan (Rahmawati, et al, 2010: 223).

Sedangkan konsep gender, adalah suatu sifat yang melekat pada kaum laki-laki maupun perempuan yang merupakan: pertama, hasil konstruksi sosial maupun kultural, misalnya perempuan dikenal lemah lembut, cantik, emotional, keibuan. Sementara lakilaki dianggap kuat, rasional, jantan, dan perkasa. Terdapat beberapa karakter dari sifat-sifat tersebut yang dapat dipertukarkan, misalnya: ada laki-laki yang lemah lembut dan emosional, sementara ada juga perempuan yang kuat dan rasional. Kedua, perubahan yang terjadi dari waktu ke waktu dan dari tempat ke tempat lain, misalnya pada jaman dulu di suatu suku terdapat perempuan lebih kuat dari laki-laki, tapi pada jaman dan tempat yang lain yang berlaku sebaliknya. Ketiga, adalah dari kelas ke kelas masyarakat yang lain yang juga berbeda. Pada perempuan kelas bawah di pedesaan pada suku tertentu lebih kuat dari laki-laki. Semua yang dapat dipertukarkan antara sifat perempuan dan laki-laki berubah dari waktu ke waktu, serta berbeda dari suatu tempat ke tempat yang lain, serta dari kelas ke kelas yang lain. Itulah yang disebut konsep gender (Fakih dalam Rahmarwati, 2010: 223).

Wanita dalam penayangan pada iklan kecap $\mathrm{ABC}$ - Jadikan masakan ibu pilihan pertama memberi simbol bahwa sosok Ibu dalam keluarga menggambarkan seorang yang 
penuh kasih sayang, tanggung jawab terhadap pekerjaan Istri seperti memasak, pengayom keluarga, serta pandai membahagiakan keluarga. Hal tersebut tampak jelas pada iklan dengan durasi 30 detik ini. Iklan tersebut menggambarkan bahwa seorang Istri harus dapat membahagiakan keluarganya dengan cara pandai memasak dan memilih produk yang tepat agar makanan yang dimasak semakin nikmat jika dihidangkan dengan keluarga. Seorang wanita yang dicintai keluarga juga tergambar pada iklan ini yaitu seseorang yang diharapkan dalam suatu keluarga. Salah satu peran Ibu dalam kehidupan sosial selain pelengkap keluarga, Ibu juga dianggap sosok yang dapat menenangkan dalam keluarga dengan dibentuknya perasaan kasih sayang yang tulus pada diri wanita membuat seorang wanita dicintai oleh keluarga. Sosok ini juga yang ditunggu-tunggu masakannya. Pada tayangan iklan kecap ABC - Jadikan masakan ibu pilihan pertama memberi petanda bahwa pilihan Istri harus bijak dalam mempersiapkan makanan.

\section{KESIMPULAN}

Setelah menganalisis hasil temuan data, maka dapat disimpulkan beberapa kesimpulan sebagai berikut :

1. Simbol yang terlihat pada iklan kecap ABC - Jadikan masakan ibu pilihan pertama yaitu rasa lapar atau selera makan yang ditunjukkan Suami terhadap Istri dengan memberi Simbol yang ditampakkan pada bahasa dan gerak tubuh Darius dengan ekspresi menghirup udara sambil memejamkan mata pertanda bahwa Darius sedang menikmati bau masakan Istri yang sedang memasak. Penanda yang muncul pada iklan tersebut yaitu Sikap yang ditunjukkan seseorang terhadap sesuatu aroma yang disukai ditandai dengan menghirup udara sambil memejamkan mata pertanda bahwa Darius sedang menikmati aroma masakan Istri yang nikmat.

2. Wanita dalam penayangan iklan kecap $A B C$ - Jadikan masakan ibu pilihan pertama memberi simbol bahwa sosok Ibu dalam keluarga menggambarkan seorang yang penuh kasih sayang, tanggung jawab terhadap pekerjaan Istri seperti memasak, pengayom keluarga, serta pandai membahagiakan keluarga. Hal tersebut tampak jelas pada iklan dengan durasi 30 detik ini. Iklan tersebut menggambarkan bahwa seorang Istri harus dapat membahagiakan keluarganya dengan cara pandai memasak dan memilih produk yang tepat agar makanan yang dimasak semakin nikmat jika dihidangkan dengan keluarga. Seorang wanita yang dicintai keluarga juga tergambar pada iklan ini yaitu seseorang yang diharapkan dalam suatu keluarga. Salah satu peran Ibu dalam kehidupan sosial selain pelengkap keluarga, Ibu juga dianggap sosok yang dapat menenangkan dalam keluarga dengan dibentuknya perasaan kasih sayang yang tulus pada diri wanita membuat seorang wanita dicintai oleh keluarga. Sosok ini juga yang ditunggu-tunggu masakannya. Pada tayangan iklan kecap ABC - Jadikan masakan ibu pilihan pertama memberi petanda bahwa pilihan Istri harus bijak dalam mempersiapkan makanan.

\section{DAFTAR PUSTAKA}

[1] Christomy, T. dan Yuwono Untung. (2004). Semiotika Budaya. Depok: Pusat Penelitian Kemasyarakatan dan Budaya Direktorat Riset dan Pengabdian Masyarakat Universitas Indonesia.

[2] Emzir. (2011). Metodologi Penelitian Kualitatif Analisis Data. Jakarta Utara: PT. RajaGrafindo Persada. 
[3] Gora Radita. (2016). Representasi Perempuan dalam Iklan Televisi, Semiotika, 2016, Vol. 10, No. 1, Juni 2016.

[4] Martono, Nanang. (2010). Metode penelitian Kuantitatif Analisa Isi dan Analisis Data Sekunder. Jakarta: PT. RajaGrafindo Persada.

[5] Mujahidah, (2010). Dinamika Gender dan Peran Perempuan dalam Ekonomi Keluarga, Jurnal Al-Ulum, Vol. 10, No. 1, Juni 2010.

[6] Prianto, Antonius. (2016). Analisis Semiotik Iklan Air Minum dalam Kemasan Aqua Versi “Keluarga Banyu” di Media Televisi, Skriptorium, 2016, Vol. 1, No. 3.

[7] Rahmawati Alvi Septi, et al (2010). Bias Gender dalam Iklan Attack Easy di Televisi, Jurnal Ilmu Komunikasi, 2010, Vol. 8, No. 3, September - Desember 2010.

[8] Rusmana, Dadan. (2014). Filsafat Semiotika. Bandung: CV. Pustaka Setia.

[9] Saifuddin, Achmad, Fedyani. (2005). Antropologi Kontemporer Suatu Pengantar Kritis

[10] Sobur, Alex. (2006). Semiotika Komunikasi. Bandung : PT Remaja Rosdakarya Bandung.

[11] Sopianah, Siti. (2010). Analisis Semiotik Terhadap Iklan Susu Bendera Edisi Ramadhan 1430 H di Televisi, Skripsi Universitas Islam Negeri Syarif Hidayatullah Jakarta.

[12] Tenggono, Calvien, Muttaqin. (2016). Analisis Semiotika Pesan Moral dalam Iklan Rokok Sampoerna A Mild "Go Ahead" di Media Televisi, Prosiding Seminar Nasional Komunikasi. Prosiding Seminar Nasional Komunikasi 2016.

\section{WEBTOGRAFI}

[13] https://www.youtube.com/watch?v=J9U1EdZRDYQ : diakses 10 Desember 2018 Pukul 09-10 WIB. 